Article

\title{
Properties of TiC and TiN Reinforced Alumina-Zirconia Composites Sintered with Spark Plasma Technique
}

\author{
Magdalena Szutkowska *, Sławomir Cygan, Marcin Podsiadło, Jolanta Laszkiewicz-Łukasik, \\ Jolanta Cyboroń and Andrzej Kalinka
}

ŁUKASIEWICZ Research Network-IAMT, 37a Wroclawska St., 30-011 Cracow, Poland;

slawomir.cygan@ios.krakow.pl (S.C.); marcin.podsiadlo@ios.krakow.pl (M.P.);

jolanta.laszkiewicz@ios.krakow.pl (J.L.-Ł.); jolanta.cyboron@ios.krakow.pl (J.C.);

andrzej.kalinka@ios.krakow.pl (A.K.)

* Correspondence: szutkows@ios.krakow.pl

Received: 4 October 2019; Accepted: 6 November 2019; Published: 13 November 2019

\begin{abstract}
In this paper, $\mathrm{Al}_{2} \mathrm{O}_{3}-\mathrm{ZrO}_{2}$ composites with an addition of $20 \mathrm{wt} \% \mathrm{TiN}$ and $10 \mathrm{wt} \% \mathrm{TiC}$ were modified. The addition of zirconia in a range from 2 to $5 \mathrm{wt} \%$ of the monoclinic phase and $10 \mathrm{wt} \%$ of $\mathrm{Y}_{2} \mathrm{O}_{3}$ stabilised $\mathrm{ZrO}_{2}$ affected the mechanical properties of the composites. A new type of sintering technique-the spark plasma sintering (SPS) method-within a temperature range from $1575{ }^{\circ} \mathrm{C}$ to $1675^{\circ} \mathrm{C}$, was used. Vickers hardness, apparent density, wear resistance and indentation fracture toughness $K_{\mathrm{IC}(\mathrm{HV})}$ were evaluated at room temperature. An increase of the sintering temperature resulted in an improvement of Vickers hardness and an increase of the fracture toughness of the tested composites. The tribological properties of the samples were tested using the ball-on-disc method. The friction coefficient was in a range from 0.31 to 0.55 , depending on the sintering temperature. An enhancement of the specific wear rate was dependent on the sintering temperature. The mechanical properties of the samples sintered by pressureless sintering (PS) were compared. X-ray diffraction patterns were presented in order to determine the phase composition. SEM microstructure of the tested composites sintered at different temperatures was observed.
\end{abstract}

Keywords: alumina-zirconia composites; $\mathrm{TiC}$; TiN; spark plasma sintering; wear resistance; indentation fracture toughness; $\mathrm{X}$-ray diffraction

\section{Introduction}

The technical performance capabilities of traditional tool materials are no longer sufficient to solve many machining problems, so these materials are successively replaced by new ones, including by sintered ceramic materials made with the use of new technologies. Due to the disappearing resources of heavy and high-melting metals and the associated high costs, the growing interest in ceramic matrix composites is also due to economic reasons. It is estimated that ceramics account for $8 \%$ of tool materials that are currently being used [1]. Among ceramics, alumina is the most important, widely used and cost-effective oxide ceramic material with perfect properties, such as high thermal resistance, good chemical stability, low density, high hardness and wear resistance, but has relatively low reliability. This is shown by the low fracture toughness $K_{\text {IC }}$ and the large dispersion of mechanical properties, reflected by the low values of the Weibull module $m$ [2]. The properties of single-phase ceramic materials do not meet all the requirements for these materials, therefore it is purposeful to use materials with a more complex structure. Ceramic matrix composites (CMCs) are systems designed to combine the excellent strength and high temperature properties of ceramics with the durability of advanced composites [3-5]. Ceramic composites in which the alumina matrix is reinforced with 
a wide range of ceramic phases including $\mathrm{TiC}, \mathrm{TiN}, \mathrm{ZrO}_{2}, \mathrm{WC}, \mathrm{NbC}, \mathrm{Ti}(\mathrm{C}, \mathrm{N}), \mathrm{SiC}, \mathrm{TiB}_{2}$, offer good strength properties, high hardness, wear resistance, chemical inertness and an improved toughness level in comparison to alumina [6-8]. The current interest in transition-metal carbides and nitrides is due to the many unique properties that these compounds exhibit. A large area of phase stability of many transition-metal carbides makes it possible to potentially tailor their thermomechanical and thermophysical properties. It is due to the crystal structure of carbides with a number of octahedral vacancies in the transition metal lattice. Titanium carbide $(\mathrm{TiC})$ belongs to metal-like carbides also called interstitial carbides. Most of the metal-like carbides retain the structure of metal in which the carbon is located inside the octahedral vacancies. In titanium carbides, it is possible to incompletely fill the octahedral vacancies. Titanium forms only monocarbides $\mathrm{TiC}_{y}$ with the widest homogeneity interval from $\mathrm{TiC}_{1.0}$ to $\mathrm{TiC}_{0.48}[9,10]$. The combination of three types of bonds-covalent, ionic and metallic-in the structure of metal-like carbides causes the material to exhibit combined features of ceramic and metallic materials, showing both high hardness (28-35 GPa), high elastic modulus (450 GPa) as well as good thermal $(22-35 \mathrm{~W} /(\mathrm{m} \cdot \mathrm{K}))$ and electrical conductivity [11]. Titanium carbide exhibits a high melting temperature $(3340 \mathrm{~K})$ and linear thermal expansion coefficient is $8.5 \times 10^{-6} \mathrm{~K}^{-1}$ [12]. Both $\mathrm{TiC}$ and $\mathrm{TiN}$ crystallize in the structure of $\mathrm{NaCl}$, where the corner of the face-centred-cubic (f.c.c.) unit cell is occupied by $\mathrm{C}$ or $\mathrm{N}$ atoms. Titanium nitride (TiN), exhibits excellent properties such as chemical stability, thermal stability, resistance to oxidation, high fracture toughness and high hardness (18-21 GPa). For the TiN phase, thermal conductivity $(29.31 \mathrm{~W} /(\mathrm{m} \cdot \mathrm{K}))$ and Young modulus $(466 \mathrm{GPa})$ are similar to that determined for $\mathrm{TiC}$, whereas the thermal expansion coefficient is slightly higher at $9.4 \times 10^{-6} \mathrm{~K}^{-1}$. The melting temperature of TiN is lower (3200 K) than that of TiC [13]. Different sintering technologies have been applied to produce the ceramic tool composites with improved mechanical properties. In pressureless sintering (PS), a low heating rate, high sintering temperature and long holding time are needed to obtain fully dense ceramic composites [14]. Spark plasma sintering (SPS) is widely used because of its great advantages compared to conventional sintering. High-speed powder consolidation, lower temperature of sintering, small holding time at the sintering temperature limit the precipitation of additional phases, resulting from unwanted reactions. SPS is a synthesis and processing technique which uses the power of a high electric pulse to generate plasma between powder particles in gaps or at the contact point, by cleaning powder surfaces (surface treatment) and increasing diffusivity at the physically contacted regions between particles [15]. The sample is heated by Joule-heating and the sparking among the particles of the sintered material leads instantaneously to faster heat and mass transfer. The basic configuration of a typical SPS system is shown in Figure 1a. Figure $1 \mathrm{~b}$ illustrates the flow of pulsed current through powder particles inside an SPS sintering die [16].

The main objective of the present study was to help establish an effect of various spark plasma sintering temperatures (change in the range of about $100^{\circ} \mathrm{C}$ ) on the properties of TiC and TiN reinforced alumina-zirconia composites with different amounts of zirconia and compare with the effects of pressureless sintering. To satisfy the industrial requirements for precision machining of hard-working pieces, the results of this study could allow new titanium carbide and titanium nitride reinforced alumina-zirconia matrix composites to be obtained that combine toughness with increased hardness. The basic way to prepare alumina matrix composites reinforced with carbides and nitrides is to use a conventional pressureless (PS) method of sintering. Full densification of these composites requires a high temperature above $1700^{\circ} \mathrm{C}$. The direct electric discharge applied in the SPS process makes it possible to achieve a highly compacted bulk material at much lower temperature (by about $150{ }^{\circ} \mathrm{C}$ ). So far, to the best of our knowledge, there have been no studies of the mechanical properties of $\mathrm{Al}_{2} \mathrm{O}_{3} / \mathrm{ZrO}_{2} /(\mathrm{TiC}+\mathrm{TiN})$ composites sintered by the SPS technique in a wide range of temperatures. Neither has there been any analysis of the influence of varying zirconium oxide content on the properties of these composites. The $\mathrm{ZrO}_{2}$ whisker reinforced $\mathrm{Ti}(\mathrm{C}, \mathrm{N})$ based cermets with addition of $\mathrm{Co}$ and WC were recently analysed [17]. Zirconia-alumina matrix composite reinforced with $\mathrm{Ti}(\mathrm{C}, \mathrm{N})$ and Ni, Ti, Mo added as binders were sintered by microwave, repetitious-hot-pressing, and HIP (Hot 
Isostatic Pressing) and tested [6,8,17-20]. Spark plasma sintering was used with good results for alumina ceramics and for $\operatorname{Ti}(\mathrm{C}, \mathrm{N})$-based cermets with the addition of a metal binder phase [21,22].
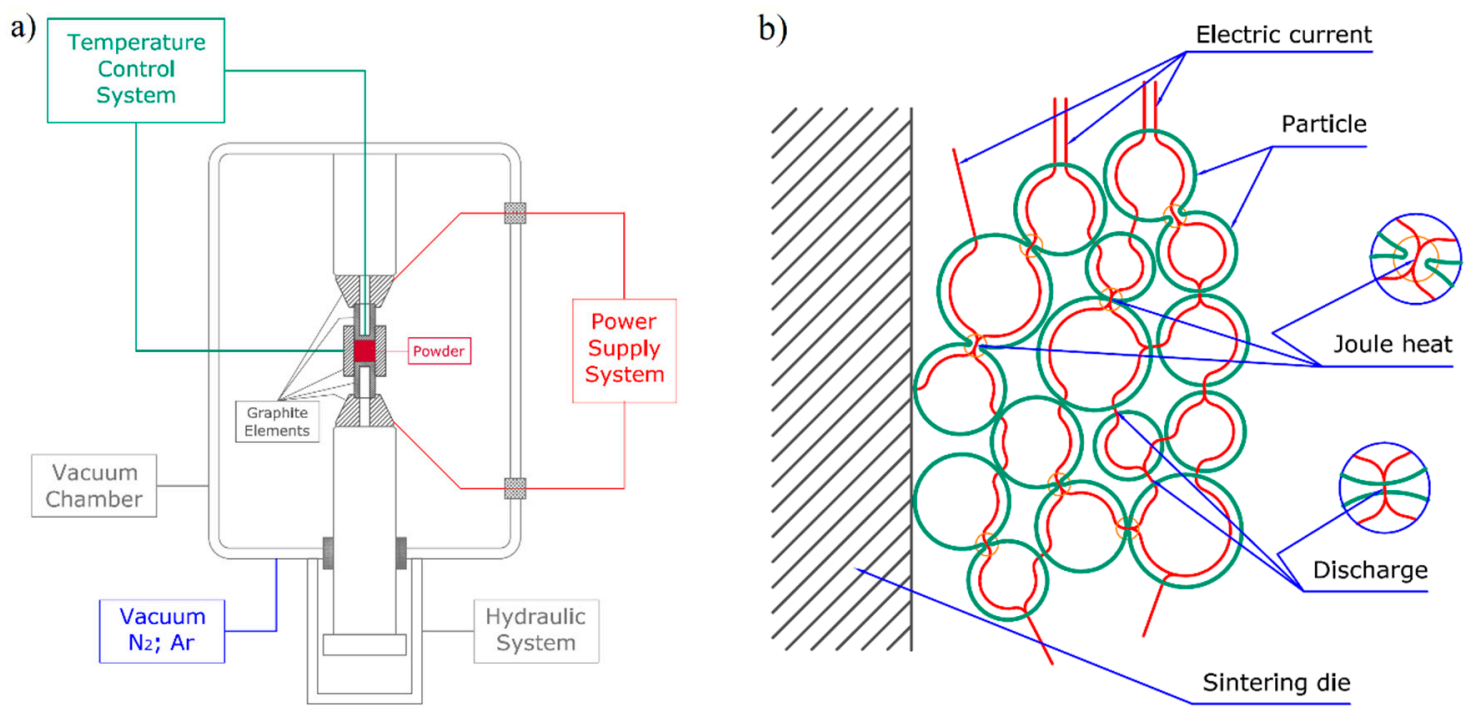

Figure 1. Spark plasma sintering (SPS) system: (a) basic configuration, (b) pulsed current flows through powder particles.

\section{Materials and Methods}

\subsection{Materials}

Commercially available powders of alumina, zirconia and titanium carbide as well as nitride were the starting materials. A high purity $\alpha-\mathrm{Al}_{2} \mathrm{O}_{3}(99.8 \%)$ powder type A16SG produced by Alcoa, United States with an average particle size of less than $0.5 \mu \mathrm{m}$ and $\mathrm{TiC}$, TiN powder in microscale $(1-3 \mu \mathrm{m})$ produced by H.C. Starck, Germany were used. The monoclinic phase of zirconia in microscale $\mathrm{ZrO}_{2}{ }^{(\mathrm{m})}$ produced by Fluka, Germany and yttria-stabilized zirconia YSZ produced by H.C. Starck, Germany with a mean particle size of 1-3 $\mu \mathrm{m}$ were added in the amount of $2 \mathrm{wt} \%, 5 \mathrm{wt} \%$ for $\mathrm{ZrO}_{2}{ }^{(\mathrm{m})}$ and $10 \mathrm{wt} \%$ for $\mathrm{YZrO}_{2}$. A small amount (less than $0.5 \mathrm{wt} . \%$ ) of magnesium oxide was added to limit grain growth. The percentage weight fraction of various components are recorded in Table 1.

Table 1. Composition of compounds.

\begin{tabular}{cccccc}
\hline \multirow{2}{*}{ Compound } & \multicolumn{5}{c}{ Components, wt $\%$} \\
\cline { 2 - 6 } & $\mathbf{A l}_{\mathbf{2}} \mathbf{O}_{\mathbf{3}}+\mathbf{M g O}$ & $\mathbf{Z r O}_{\mathbf{2}}{ }^{(\mathbf{m})}$ & $\mathbf{Y Z r O}{ }_{\mathbf{2}}$ & $\mathbf{T i C}$ & $\mathbf{T i N}$ \\
\hline $\mathrm{TCN} 1$ & 68 & 2 & - & 10 & 20 \\
$\mathrm{TCN} 2$ & 65 & 5 & - & 10 & 20 \\
$\mathrm{TCN} 3$ & 60 & - & 10 & 10 & 20 \\
\hline
\end{tabular}

Components with plasticiser were mixed in alumina mills with zirconia balls, for thirty hours. The powders after plasticising and drying, were granulated and directly fed into the graphite dies. The compounds were consolidated in a spark plasma sintering system at different temperatures from $1575^{\circ} \mathrm{C}$ to $1675^{\circ} \mathrm{C}$ at a heating rate of $100^{\circ} \mathrm{C} / \mathrm{min}$ and under a pressure of $35 \mathrm{MPa}$. Holding time at peak temperature was $10 \mathrm{~min}$. Figure 2 presents the change in the temperature and in piston displacement during SPS sintering of alumina-zirconia powders with TiC and TiN. 


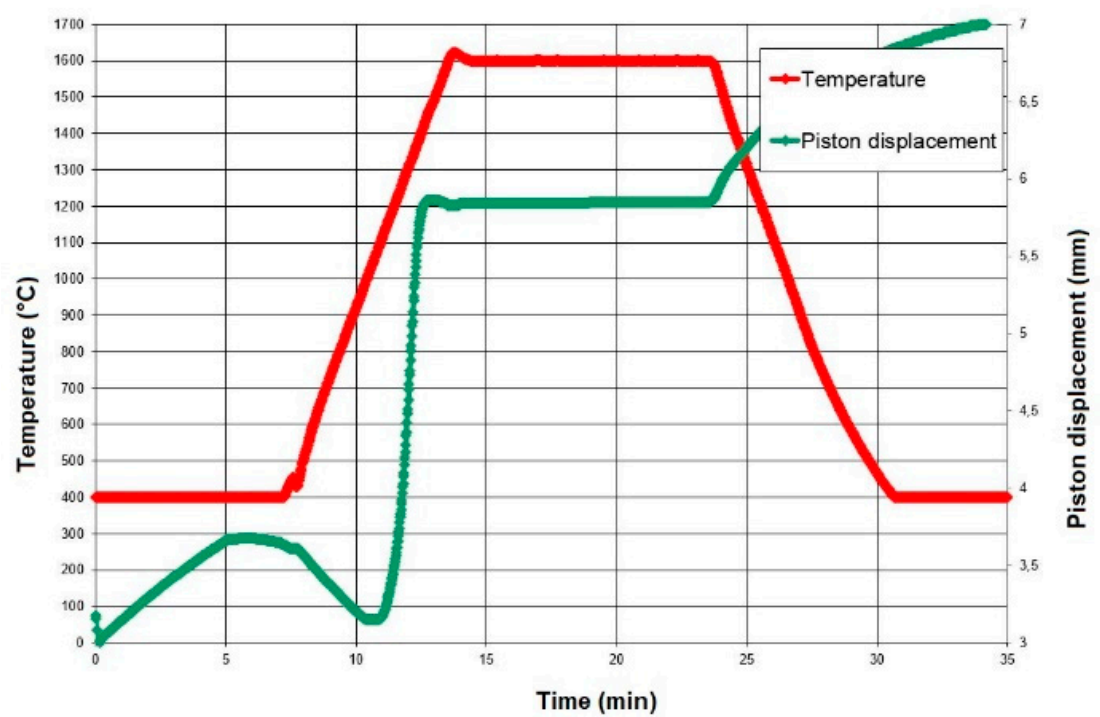

Figure 2. Sintering curve of alumina-zirconia powders with TiC and TiN.

Furnace type FCT HD5 (FCT Systeme GmbH, Frankenblick, Germany) under argon conditions was used. The final sintered sample was in a shape of a disk with a diameter of $20 \mathrm{~mm}$ and about $5.0 \mathrm{~mm}$ in thickness. Furthermore, the samples were sintered by pressureless sintering (PS) in the HTK8 Gero furnace (Carbolite Gero GmbH \& Co. KG, Neuhausen, Germany) in argon atmosphere, at a $1750{ }^{\circ} \mathrm{C}$ temperature and a heating rate of $100{ }^{\circ} \mathrm{C} / \mathrm{min}$. The temperature was controlled using an optical pyrometer. The sintering time was $1 \mathrm{~h}$. After sintering the specimens were plane ground with diamond (MD-Piano120), and also fine ground with diamond grains of about $3 \mu \mathrm{m}$ (MD-Largo). Before measuring the mechanical properties and microstructural observation the specimens were polished with an OP-S type colloidal silica (size of silicon oxide grains of about $0.04 \mu \mathrm{m}$ ). The roughness $R_{a}$ of the tested surface was not more than $0.1 \mu \mathrm{m}$.

\subsection{Characterisation}

The following measurements were performed: Vickers hardness HV1, Young's modulus $E$, friction coefficient $\mu$, (in ball-on-disc tests, using a UMT-2MT universal mechanical tester produced by CETR, Campbell, CA, USA), relative density and apparent density $\rho$, according to the EN 623-2 standard [23]. The Vickers hardness HV1 was measured under a load of $9.81 \mathrm{~N}$ using a digital hardness tester (FV-700 by FUTURE-TECH CORP., Kawasaki, Japan). The standard deviations of five hardness measurements made for each sample did not exceed $2 \%$ of the average values. Ultrasonic method based on velocity measurements of transversal and longitudinal waves in the samples has been used to determine the Young's modulus E. The test stand for ultrasonic measurements consisted of an ultrasonic flaw detector (Epoch III by Panametrics, Waltham, MA, USA), a set of special broadband heads emitting longitudinal or transversal waves. The whole system operated under the control of a specialized software for data collection and processing. The following formula was used for calculation of Young's modulus [24]:

$$
E=\rho C_{T}^{2} \frac{3 C_{L}^{2}-4 C_{T}^{2}}{C_{L}^{2}-C_{T}^{2}}
$$

where $\rho$-apparent density, $C_{L}$-velocity of the longitudinal wave, $C_{T}$-velocity of the transversal wave.

The point indentation technique has found application in the study of the indentation fracture toughness. The indentation fracture toughness $K_{\mathrm{IC}(\mathrm{HV})}$ was evaluated from a direct measurement of the crack length as a function of the indentation load called the "direct crack measurement" (DCM). The "halfpenny" shaped, elliptical cracks formed during the Vickers hardness indentation gave a 
basis to determine the indentation fracture toughness $K_{\mathrm{IC}(\mathrm{HV})}$. For these cracks the ratio $\mathrm{c} / \mathrm{a} \geq 2.5$ was observed and the indentation fracture toughness was defined as follows [25]:

$$
\left(K_{\mathrm{IC}(\mathrm{HV})} \varphi / \mathrm{Ha}^{1 / 2}\right)(H / E \varphi)^{2 / 5}=0.129(\mathrm{c} / \mathrm{a})^{-3 / 2}
$$

where $K_{\mathrm{IC}(\mathrm{HV})}$ is the critical stress intensity factor, $\varphi$ is the constrain factor, $H$ is the Vickers hardness, $E$ is the Young's modulus, a is half the length of indent diagonal, $\mathrm{c}$ is the sum of a and 1 (crack length).

The pressing-in load used to produce the Vickers cracks was of $294.3 \mathrm{~N}$. Tribological research using the ball-on-disc method, with the use of a universal UMT-2-MT mechanical equipment was carried out. The friction coefficient and the specific wear rate of the disk-shaped samples in contact with $\mathrm{Al}_{2} \mathrm{O}_{3}$ ball were measured. In this method, sliding contact is possible by pressure of the ball specimen onto a rotating disk specimen under a constant load. Using a controlled load $F_{n}$ to the ball holder, the friction force was measured continuously during the test with an extensometer. For each test, a new ball was used. The ball and disk samples were washed in ethyl alcohol and dried. The diameter of the disk-shaped samples was of $20 \mathrm{~mm}$ and about $5.0 \mathrm{~mm}$ in height. The following test conditions were adopted: ball diameter of $3.2 \mathrm{~mm}$, applied load of $20 \mathrm{~N}$, sliding speed of $0.1 \mathrm{~m} / \mathrm{s}$, radius of the sliding circle of $4 \mathrm{~mm}$, sliding distance of $2000 \mathrm{~m}$ and time of the test of 20,000 s. The specimens were tested without lubricant at room temperature. Each test was repeated on three specimens. The friction coefficient was expressed as follows:

$$
\mu=\frac{F_{f}}{F_{n}}
$$

where $\mu$-friction coefficient, $F_{f}-$ measured friction force, $F_{n}$-applied normal force.

After the test, the cross-sectional profile of the wear track in four places at intervals of $90^{\circ}$ was measured using a contact stylus profilometer PRO500 (CETR, Campbell, CA, USA), according to the ISO 20808:2016 standard [26]. Then, the average cross-sectional area of the wear track was calculated. The volume of removed material was evaluated as a product of the cross-sectional area of the wear track and its circumference. The specific wear rate can then be defined using Equation (4):

$$
\mathrm{Ws}=\frac{V}{F_{n} \cdot L}
$$

where $\mathrm{W}_{\mathrm{s}}$-specific wear rate, $V$-volume of removed material, $L$-sliding distance.

The microstructure observations of the specimen were characterised using JEOL JSM-6460LV (JEOL Ltd., Tokyo, Japan) scanning electron microscope equipped with EDS (Energy-dispersive X-ray spectroscopy), EBSD (Electron Backscatter Diffraction), WDS (Wavelength-Dispersive X-ray Spectroscopy). XRD measurements were taken using an Empyrean system (PANAlytical, Malvern, $\mathrm{UK})$ with $\mathrm{Cu} K \alpha 1$ radiation. The phase compositions of the sintered compacts were identified using the database of International Centre for Diffraction Data (Newtown Square, PA, USA) PDF4+2018. The quantitative compositions of the tested composites were determined by the Rietveld method with the X'Pert Plus program (PANAlytical, Malvern, UK).

\section{Results and Discussion}

Table 2 shows the average values of the following properties of the tested alumina matrix composites TCN1, TCN2, TCN3 at sintering temperatures from $1575{ }^{\circ} \mathrm{C}$ to $1675{ }^{\circ} \mathrm{C}$ : apparent density, relative density and Young modulus. Samples of the TCN1 composition sintered by pressureless sintering (PS) were marked TCN1*. 
Table 2. Apparent density, relative density and Young modulus of the tested composites.

\begin{tabular}{ccccc}
\hline Sample & $\begin{array}{c}\text { Sintering Temperature } \\
\left({ }^{\circ} \mathbf{C}\right)\end{array}$ & $\begin{array}{c}\text { Apparent Density } \boldsymbol{\rho} \\
\left(\mathbf{g} / \mathbf{c m}^{\mathbf{3}} \mathbf{)}\right.\end{array}$ & $\begin{array}{c}\text { Relative Density } \\
\mathbf{( \% )}\end{array}$ & $\begin{array}{c}\text { Young Modulus } \boldsymbol{E} \\
\mathbf{( G P a )}\end{array}$ \\
\hline TCN1.1 & 1575 & $4.26 \pm 0.01$ & 98.18 & $412 \pm 5.0$ \\
TCN1.2 & 1600 & $4.29 \pm 0.01$ & 98.87 & $418 \pm 5.0$ \\
TCN1.3 & 1625 & $4.28 \pm 0.01$ & 98.64 & $416 \pm 5.0$ \\
TCN1.4 & 1650 & $4.29 \pm 0.01$ & 98.87 & $415 \pm 4.5$ \\
TCN1.5 & 1675 & $4.29 \pm 0.01$ & 98.87 & $421 \pm 4.5$ \\
TCN2.1 & 1575 & $4.34 \pm 0.01$ & 98.89 & $411 \pm 5.0$ \\
TCN2.2 & 1600 & $4.33 \pm 0.01$ & 98.67 & $405 \pm 5.0$ \\
TCN2.3 & 1625 & $4.34 \pm 0.01$ & 98.89 & $412 \pm 5.0$ \\
TCN2.4 & 1650 & $4.34 \pm 0.01$ & 98.89 & $407 \pm 4.5$ \\
TCN2.5 & 1675 & $4.33 \pm 0.01$ & 98.67 & $406 \pm 5.0$ \\
TCN3.1 & 1575 & $4.43 \pm 0.01$ & 98.01 & $404 \pm 4.5$ \\
TCN3.2 & 1600 & $4.43 \pm 0.01$ & 98.01 & $400 \pm 5.0$ \\
TCN3.3 & 1625 & $4.44 \pm 0.01$ & 98.23 & $403 \pm 4.5$ \\
TCN3.4 & 1650 & $4.44 \pm 0.01$ & 98.23 & $407 \pm 5.0$ \\
TCN3.5 & 1675 & $4.44 \pm 0.01$ & 98.23 & $405 \pm 5.0$ \\
TCN1 & 1750 & $4.21 \pm 0.01$ & 97.03 & $378 \pm 4.0$ \\
\hline
\end{tabular}

Notice: TCN1* specimen was sintered by the pressureless sintering (PS) method.

The values of Vickers hardness HV1 and indentation fracture toughness $K_{\mathrm{IC}(\mathrm{HV})}$ are presented in Figures 3 and 4 .

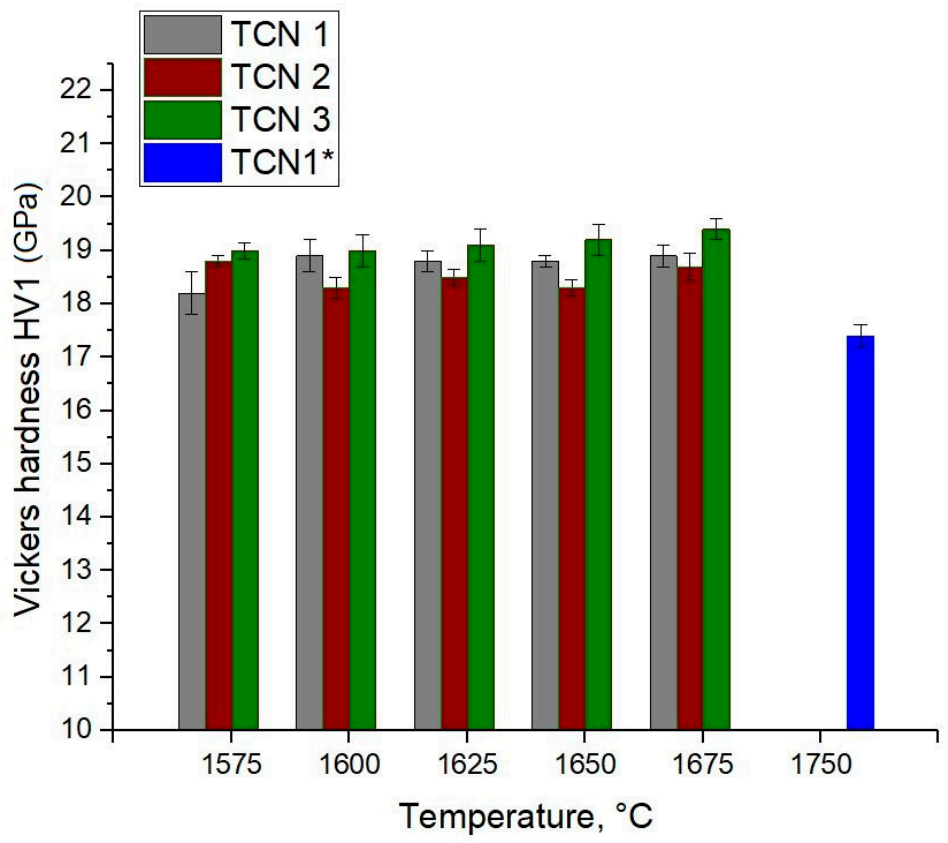

Figure 3. Vickers hardness versus sintering temperature for the tested composites: TCN1, TCN2, TCN3 and TCN1*.

Titanium carbide and nitride reinforced alumina matrix composites consolidated through SPS exhibited: Vickers hardness $H V 1$ from 19.4 GPa to $18.2 \mathrm{GPa}$, critical stress intensity factor $K_{\mathrm{IC}(\mathrm{HV})}$ from $3.84 \mathrm{MPa} \cdot \mathrm{m}^{1 / 2}$ to $5.83 \mathrm{MPa} \cdot \mathrm{m}^{1 / 2}$, Young modulus from $400 \mathrm{GPa}$ to $421 \mathrm{GPa}$, apparent density from $4.26 \mathrm{~g} / \mathrm{cm}^{3}$ to $4.44 \mathrm{~g} / \mathrm{cm}^{3}$, and relative density from $98.18 \%$ to $98.89 \%$. Samples sintered by SPS marked as TCN3 had the Vickers hardness value of over 19.0 GPa. The results showed no significant influence of the sintering temperature on the mechanical properties of these composites. There was only $1-2 \%$ difference in Vickers hardness between TCN3 samples measured at the lowest $\left(1575^{\circ} \mathrm{C}\right)$ and highest $\left(1675^{\circ} \mathrm{C}\right)$ temperatures. The Vickers hardness for TCN1 and TCN2 composites was slightly lower and was in the range between 18.2 and $18.9 \mathrm{GPa}$. The effect of the sintering temperature on 
the Vickers hardness HV1 was not observed for TCN1 and TCN2 composites manufactured with the content of the $\mathrm{ZrO}_{2}{ }^{(\mathrm{m})}$ zirconia phase of $2 \mathrm{wt} \%$ and $5 \mathrm{wt} \%$ respectively. However, an effect of the sintering temperature on the indentation fracture toughness of the tested composites was observed (Figure 2). The indentation fracture toughness of the tested composites increased by $10-20 \%$ as the temperature used was increased. TCN1 and TCN2 composites show a high value of $K_{\mathrm{IC}(\mathrm{HV})}$ (about $6.0 \mathrm{MPa} \cdot \mathrm{m}^{1 / 2}$ ) at the highest temperature of $1675^{\circ} \mathrm{C} . K_{\mathrm{IC}(\mathrm{HV})}$ of TCN3 at $1675^{\circ} \mathrm{C}$ was about $4.4 \mathrm{MPa} \cdot \mathrm{m}^{1 / 2}$. After pressureless sintering of the $\mathrm{TCN} 1^{*}$ specimen at the highest temperature of $1750^{\circ} \mathrm{C}$, the following mechanical and physical properties were obtained: Vickers hardness $H V 1$ of $17.4 \mathrm{GPa}$, critical stress intensity factor $K_{\mathrm{IC}(\mathrm{HV})}$ of $4.46 \mathrm{MPa} \cdot \mathrm{m}^{1 / 2}$, Young modulus of $378 \mathrm{GPa}$, apparent density of $4.21 \mathrm{~g} / \mathrm{cm}^{3}$, and relative density of $97.03 \%$. Although such a high sintering temperature was used for this specimen, its mechanical properties were 10-25\% lower compared to specimens sintered at the highest temperature $\left(1675{ }^{\circ} \mathrm{C}\right)$ and even $5-10 \%$ lower compared to those sintered at the lowest temperature $\left(1575{ }^{\circ} \mathrm{C}\right)$. The X-ray diffraction analysis of the composites with a different amount of zirconia phase at the sintering temperature of $1600{ }^{\circ} \mathrm{C}$ (marked as TCN1.2, TCN2.2 and TCN3.2) indicated the presence of the following phases: $\mathrm{Al}_{2} \mathrm{O}_{3}, \mathrm{Ti}(\mathrm{C}, \mathrm{N}), \mathrm{TiC}, \mathrm{TiN}, \mathrm{ZrO}_{2}$ in monoclinic and tetragonal forms and titanium aluminium oxide $\left(\mathrm{Ti}_{0.25} \mathrm{Al}_{1.75} \mathrm{O}_{3}\right)$ - see Figure 5 .

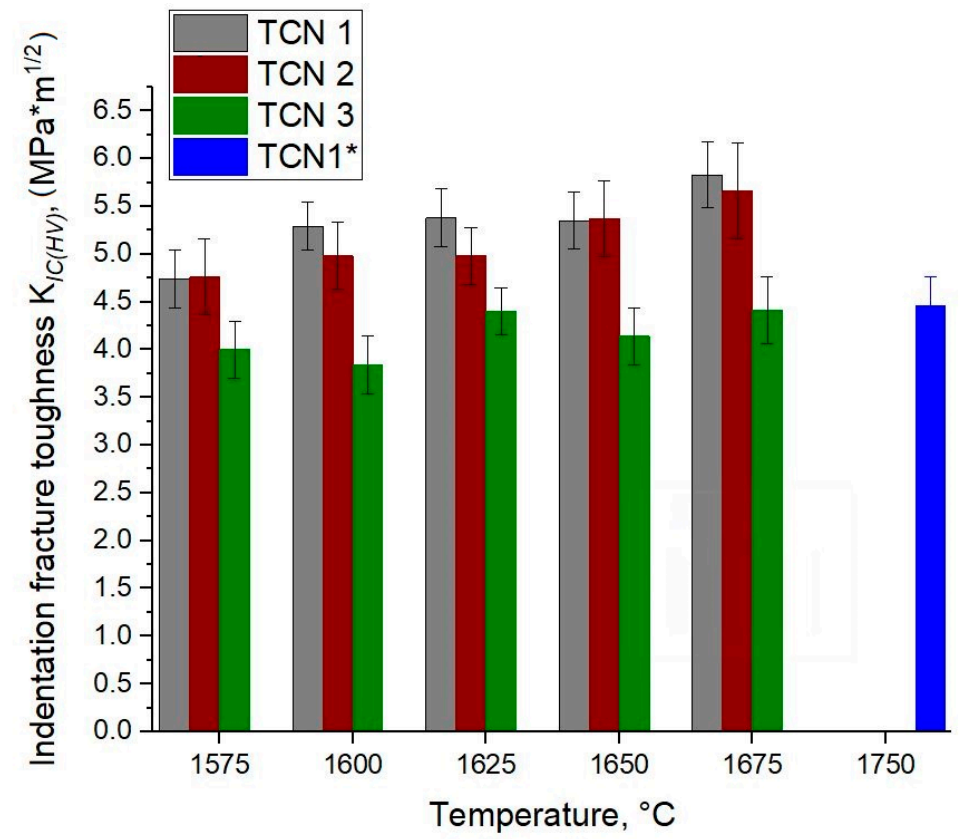

Figure 4. Indentation fracture toughness versus sintering temperature for the tested composites: TCN1, TCN2, TCN3 and TCN1*.

The peak of the titanium aluminium oxide was not visible in the X-ray diffraction pattern because it correlated with the alumina peak. The quantitative phase composition obtained by X-ray diffraction analysis of the composites with $2 \mathrm{wt} \%$ of $\mathrm{ZrO}_{2}{ }^{(\mathrm{m})}, 5 \mathrm{wt} \%$ of $\mathrm{ZrO}_{2}{ }^{(\mathrm{m})}$, and $10 \mathrm{wt} \%$ of $\mathrm{YZrO}_{2}{ }^{(\mathrm{t})}$ (marked as TCN1, TCN2, TCN3, respectively) is presented in Table 3.

Table 3. X-ray diffraction analysis of the tested composites.

\begin{tabular}{ccccccc}
\hline \multirow{2}{*}{ Composite } & \multicolumn{7}{c}{ Content (wt\%) } \\
\cline { 2 - 7 } & $\mathbf{A l}_{\mathbf{2}} \mathbf{O}_{3}$ & $\mathrm{TiN}$ & $\mathrm{TiC}$ & $\mathrm{Ti}(\mathrm{C}, \mathbf{N})$ & $\mathrm{ZrO}_{\mathbf{2}}{ }^{(\mathbf{m})}$ & $\mathrm{ZrO}_{2}{ }^{(\mathbf{t})}$ \\
\hline TCN1 & 68.0 & 17.0 & 8.0 & 5.0 & 1.0 & 1.0 \\
TCN2 & 66.0 & 14.0 & 4.0 & 12.0 & 2.0 & 2.0 \\
TCN3 & 59.0 & 12.0 & 4.0 & 15.0 & - & 10.0 \\
\hline
\end{tabular}



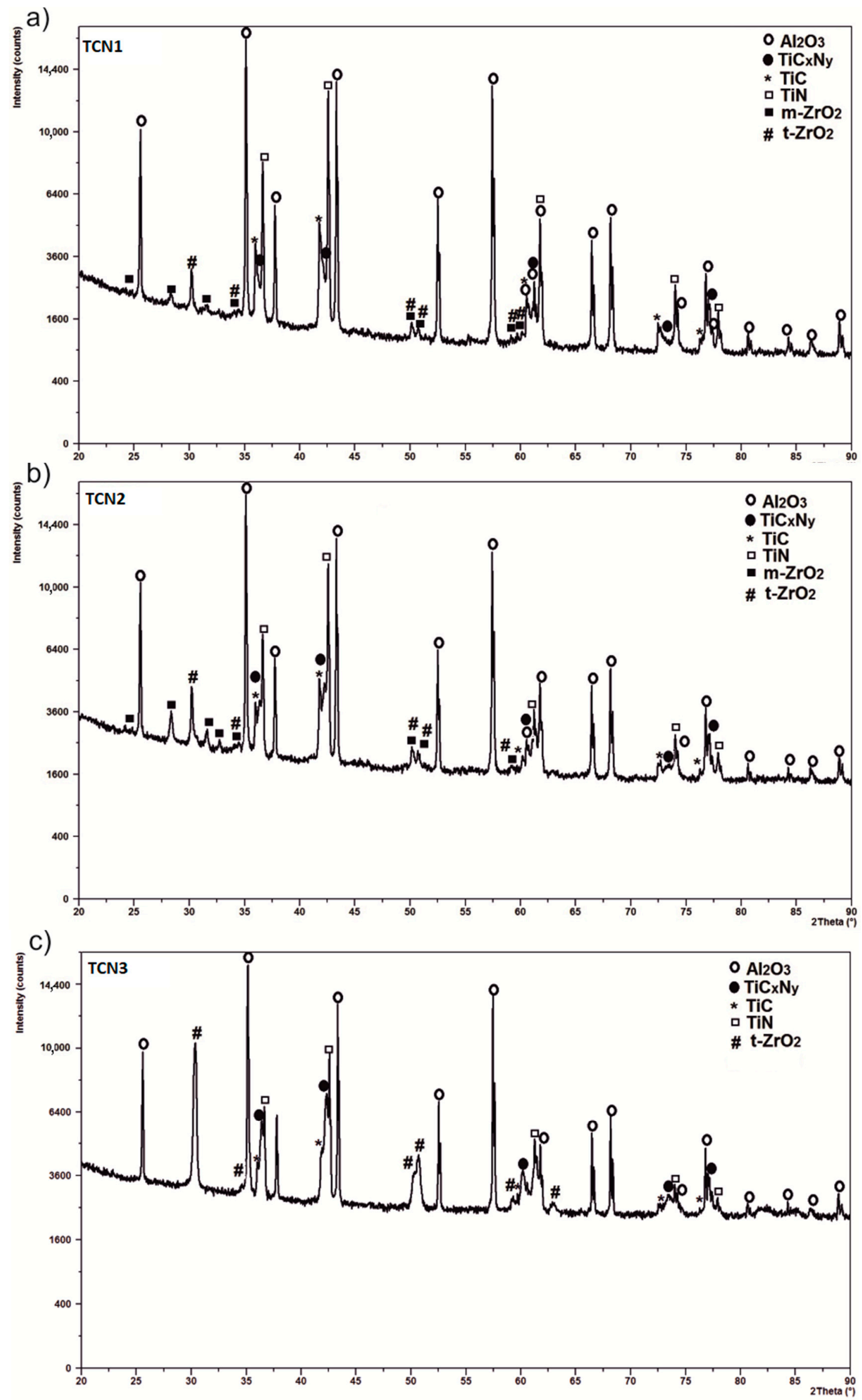

Figure 5. X-ray diffraction pattern of the $\mathrm{Al}_{2} \mathrm{O}_{3} / \mathrm{ZrO}_{2} /(\mathrm{TiC}+\mathrm{TiN})$ composites: (a) TCN1; (b) TCN2; (c) TCN3. 
Tetragonal $\mathrm{ZrO}_{2}{ }^{(\mathrm{t})}$ and monoclinic $\mathrm{ZrO}_{2}{ }^{(\mathrm{m})}$ phases in the specimens TCN1 and TCN2 with the addition of $2 \mathrm{wt} \%$ and $5 \mathrm{wt} \%$ monoclinic $\mathrm{ZrO}_{2}{ }^{(\mathrm{m})}$ were observed. This was due to partial polymorphic transformation with the martensitic nature of monoclinic $\mathrm{ZrO}_{2}{ }^{(\mathrm{m})}$ into tetragonal $\mathrm{ZrO}_{2}{ }^{(\mathrm{t})}$. The TCN3 composite revealed only zirconia tetragonal phase $\mathrm{ZrO}_{2}{ }^{(\mathrm{t})}$. The analysis of the X-ray diffraction of the tested composites showed the highest amount of $\operatorname{Ti}(C, N)$ was a continuous solution of $\operatorname{TiN}$ and $\mathrm{TiC}$ for the TCN3 specimen. A SEM image of the indentation crack path in $\mathrm{Al}_{2} \mathrm{O}_{3} / \mathrm{ZrO}_{2} /(\mathrm{TiC}+\mathrm{TiN})$ composites (marked as TCN1 and TCN3) is presented in Figure 6a,b.

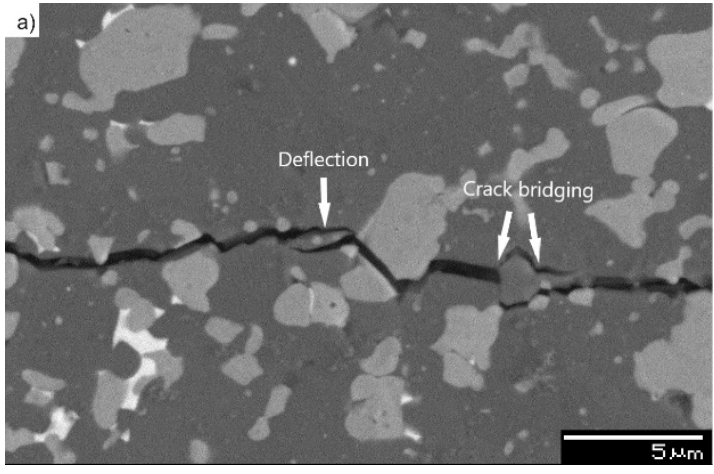

(a)

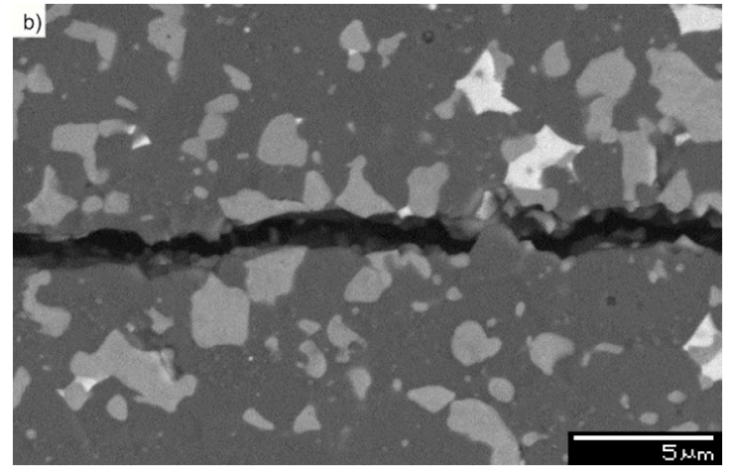

(b)

Figure 6. SEM image of indentation crack path in $\mathrm{Al}_{2} \mathrm{O}_{3} / \mathrm{ZrO}_{2} /(\mathrm{TiC}+\mathrm{TiN})$ composites:(a) TCN1.5; (b) TCN3.5.

The microstructures of the tested composites revealed transgranular and intergranular fractures during crack propagation. The presence of the transgranular fracture is favourable for the enhancement of toughness in these composites. Furthermore, crack bridging and crack deflection were observed for TCN1 specimen (Figure 6a). The transgranular fracture absorbs more energy, and it improves the strength properties of composites. The presence of the crack bridging can provide a force to make the two surfaces of the crack draw closely, thus the crack propagation is limited [14].

SEM microstructural observations of the ceramic composites showed their good consolidation. The EDS technique was used to carry out surface distribution analysis and semi-quantitative microanalysis of the elements present in the specimens, revealing the following phases: $\mathrm{TiN}, \mathrm{TiC}$, $\mathrm{Ti}(\mathrm{C}, \mathrm{N}), \mathrm{ZrO}_{2}, \mathrm{MgO}$ (Figure 7).

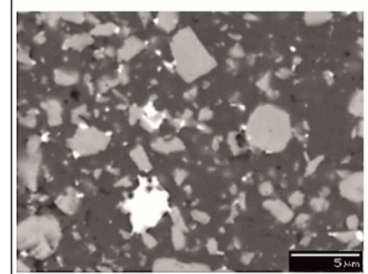

Electron Image 1

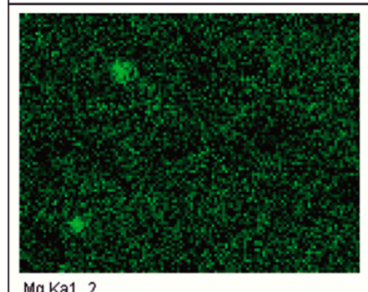

Mg Ka1_2
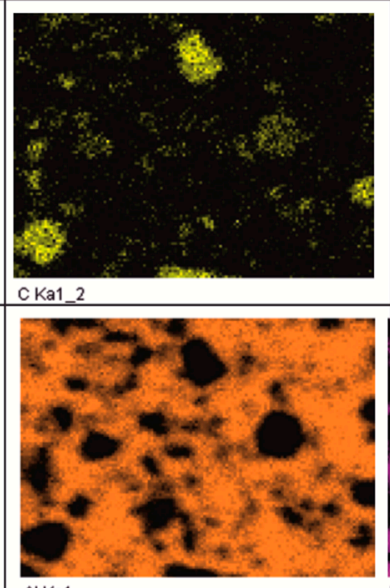

Al Ka1

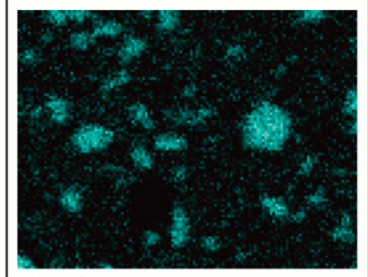

NKa1_2

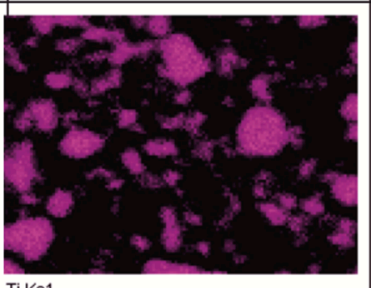

Ti Ka1

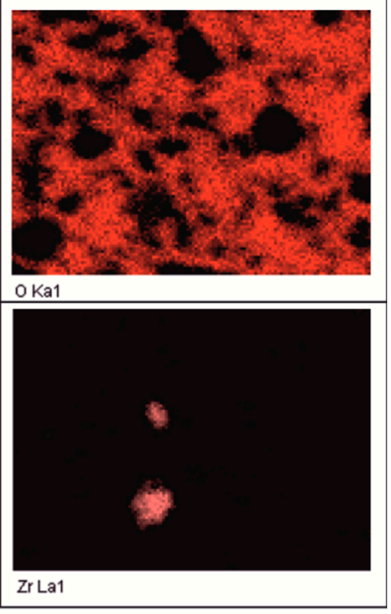

Figure 7. Distribution of the elements in the TCN1.1 composite.

Figure 8 presents microstructure images for the tested $\mathrm{Al}_{2} \mathrm{O}_{3} / \mathrm{ZrO}_{2} /(\mathrm{TiC}+\mathrm{TiN})$ composites sintered at $1575^{\circ} \mathrm{C}$ and $1675^{\circ} \mathrm{C}$. The microstructures of the composites with an addition of $2 \mathrm{wt} \%$ and $5 \mathrm{wt} \%$ 
$\mathrm{ZrO}_{2}{ }^{(\mathrm{m})}$ (marked TCN1 and TCN2, respectively) sintered at $1575{ }^{\circ} \mathrm{C}$ were similar. TiC and TiN grains of differential sizes (fine to coarse) and shapes were distributed in the alumina matrix. Apart from single zirconia grains, zirconia grain agglomerates also occurred (Figure $8 \mathrm{a}, \mathrm{c}$ ). The average grain size of $\mathrm{TiC}$ and $\mathrm{TiN}$ is within the range of $2.7 \mu \mathrm{m}$ to $3.0 \mu \mathrm{m}$. In TCN3 composites with the addition of $10 \mathrm{wt} \%$ yttria-stabilised zirconia, TiC and TiN grains exhibit a similar shape and a smaller size in comparison with TCN1 and TCN2 composites. The average grain size of $\mathrm{TiC}$ and $\mathrm{TiN}$ was about $2.4 \mu \mathrm{m}$. However, the grains of $\operatorname{Ti}(\mathrm{C}, \mathrm{N})$ solid solution in the composites sintered at $1675{ }^{\circ} \mathrm{C}$ were observed to have a rounder shape (Figure $8 \mathrm{~b}, \mathrm{~d}, \mathrm{f})$. The grain size of $\mathrm{Ti}(\mathrm{C}, \mathrm{N})$ was from $1.9 \mu \mathrm{m}$ to $2.3 \mu \mathrm{m}$. The presence of $\mathrm{Ti}(\mathrm{C}, \mathrm{N})$ solid solution in the microstructure of the composites changed their properties. The friction coefficient for the tested composites was in the range of 0.31 to 0.55 (Figure 9).
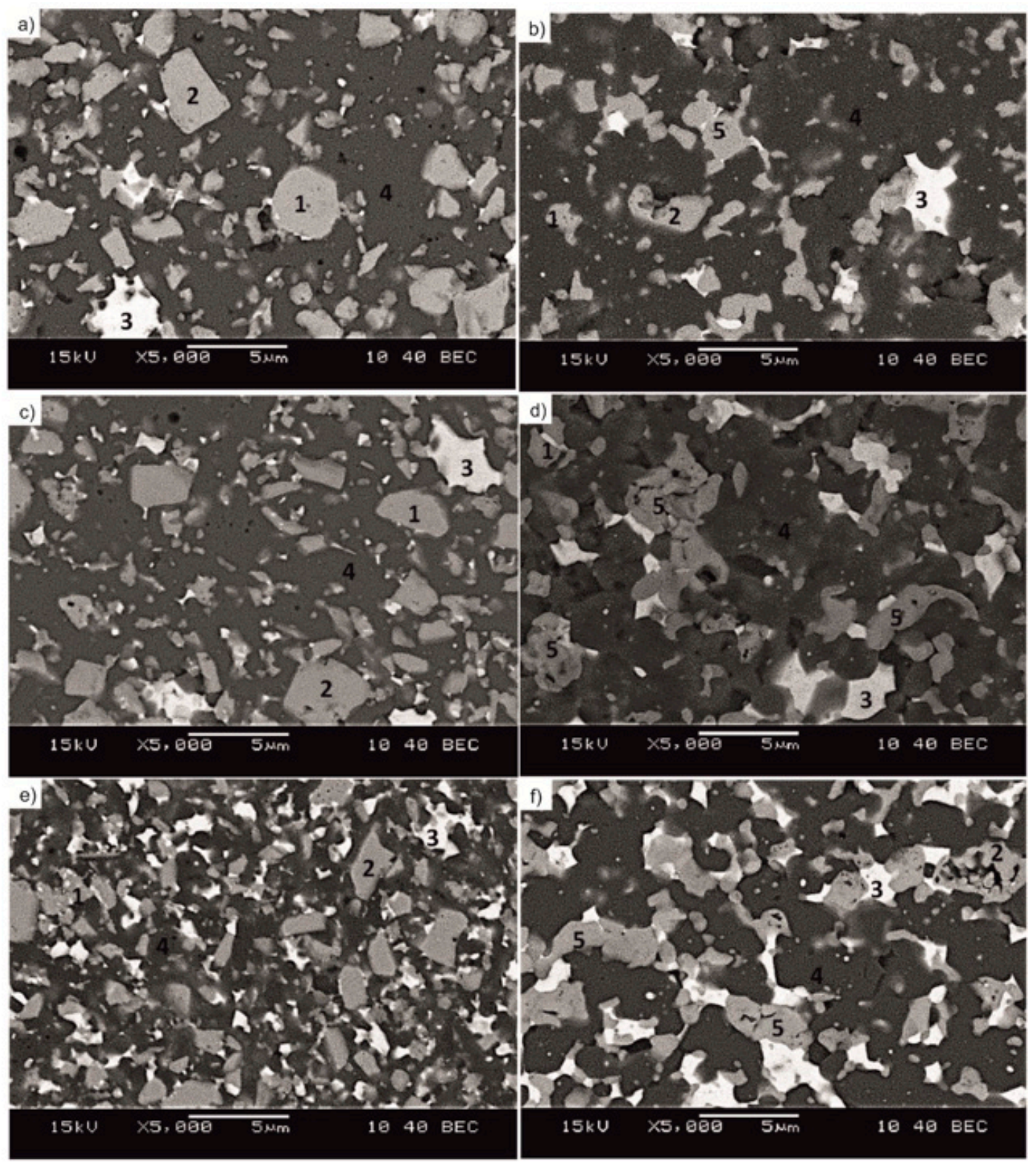

Figure 8. SEM microstructure of the $\mathrm{Al}_{2} \mathrm{O}_{3} / \mathrm{ZrO}_{2} /(\mathrm{TiC}+\mathrm{TiN})$ composites for: (a) TCN1.1, (b) TCN1.5, (c) TCN2.1, (d) TCN2.5, (e) TCN3.1, (f) TCN3.5, where: 1- TiN, 2- TiC, 3- $\mathrm{ZrO}_{2}, 4-\mathrm{Al}_{2} \mathrm{O}_{3}, 5-\mathrm{Ti}(\mathrm{C}, \mathrm{N})$. 


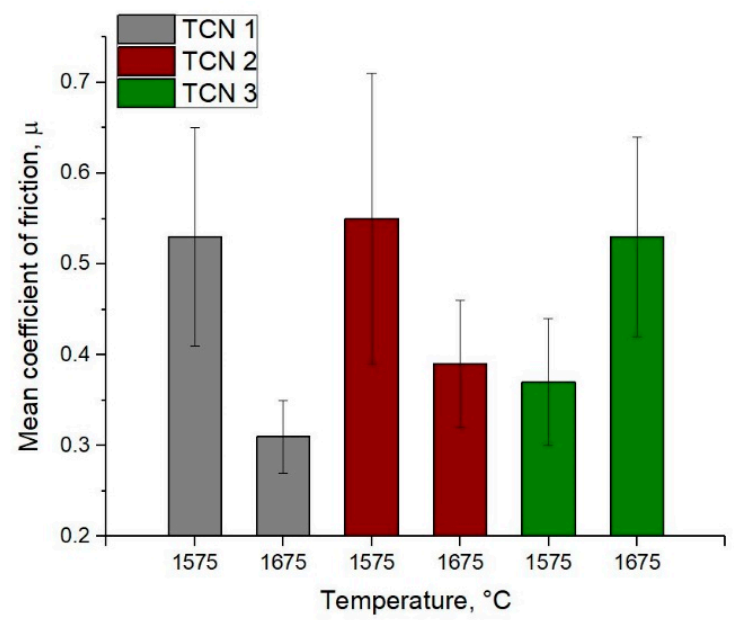

Figure 9. Mean friction coefficient of the tested composites.

An increased sintering temperature of up to $1675{ }^{\circ} \mathrm{C}$ resulted in a lower friction coefficient for specimens TCN1 and TCN2 with the addition of $2 \mathrm{wt} \%$ and $5 \mathrm{wt} \%$ monoclinic $\mathrm{ZrO}_{2}$ phase, respectively, whereas the TCN3 composite with $10 \mathrm{wt} \%$ of yttria-stabilised zirconia (YSZ) exhibited an inverse correlation.

For all the composites tested, a higher sintering temperature caused an increase in the wear rate of both the disk and the ball (Figure 10).

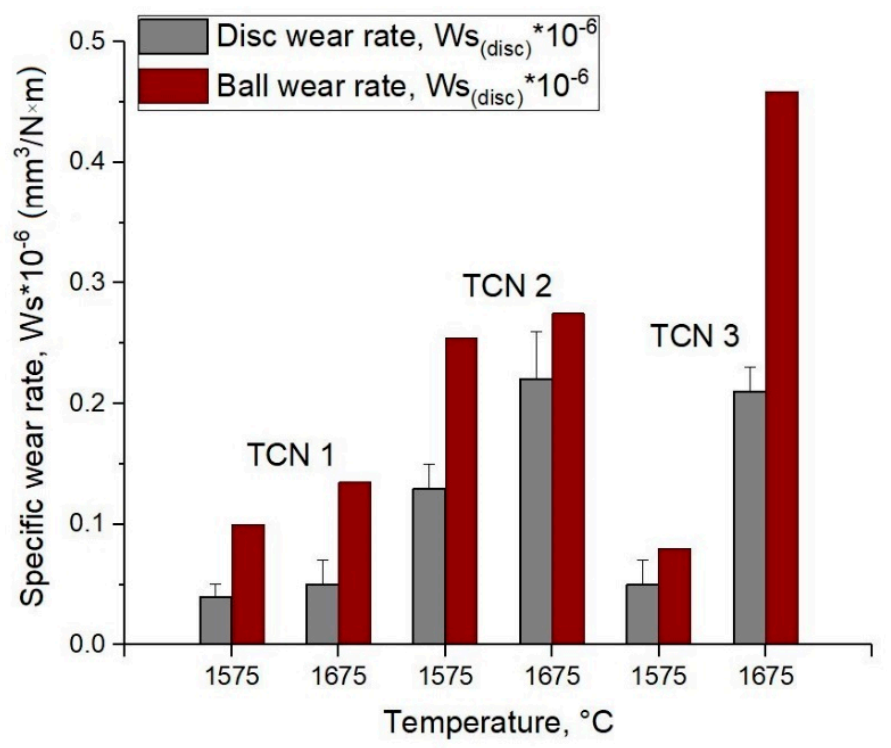

Figure 10. Specific wear rate for disc and ball for tested composites.

The improvement of mechanical properties were attributed to the increased rate of densification in spark plasma sintering and to microstructural changes. The presence of $\operatorname{Ti}(\mathrm{C}, \mathrm{N})$ solid solution in the microstructure of the composites changed their properties. The content of $15 \mathrm{wt} \% \operatorname{Ti}(\mathrm{C}, \mathrm{N})$ solid solution with high Vickers hardness of $30.0 \mathrm{GPa}$, with the TiC phase reduced to $40 \mathrm{wt}$. $\%$ resulted in a higher Vickers hardness and lower indentation fracture toughness of the specimens. Moreover, character of fracture and crack propagation was an additional parameter in improvement properties. Both the transgranular fracture and the crack bridging observed for crack propagation resulted in improved fracture toughness of tested alumina-zirconia matrix composites. Using the SPS technique to consolidate alumina-zirconia powder with the addition of $\mathrm{TiC}$ and $\mathrm{TiN}$, it was possible to obtain a high-density ceramic material with the following characteristics: over $98 \%$ density in the temperature 
range of $1575-1675^{\circ} \mathrm{C}$, Vickers hardness of about $19.0 \mathrm{GPa}$, fracture toughness of over $5.0 \mathrm{MPa} \mathrm{m}^{1 / 2}$. These properties were significantly better than those obtained by pressureless sintering. To the best of our knowledge, no study results of TiC- and TiN-reinforced alumina-zirconia composites (with various amount of zirconia) manufactured by SPS technique have been presented in literature. Therefore, it is not possible to compare the results obtained in this study with other results obtained in similar conditions. While the influence of the most important operating parameters on product characteristics after consolidation/synthesis of ceramic materials by electric current activated/assisted was widely discussed in the last decade $[27,28]$, attention was focussed on alumina ceramics, alumina-zirconia composites and alumina matrix composites reinforced with $\mathrm{SiC}, \mathrm{TiC}, \mathrm{Ti}_{3} \mathrm{SiC}_{2}, \mathrm{TiN}$, graphene platelets (GPls) [29]. $\mathrm{Al}_{2} \mathrm{O}_{3}$ ceramics were super-fast densified by SPS at temperatures ranging between $1350{ }^{\circ} \mathrm{C}$ and $1700^{\circ} \mathrm{C}\left(600{ }^{\circ} \mathrm{C} / \mathrm{min}\right.$ heating rate $)$ at $40 \mathrm{MPa}$, without selecting a holding time. Full densification of the samples was observed at sintered temperatures below $1550{ }^{\circ} \mathrm{C}$. However, full densification of $\mathrm{Al}_{2} \mathrm{O}_{3}-40 \mathrm{wt} \% \mathrm{TiC}$ nanocomposite powders was achieved at a sintering temperature of $1480^{\circ} \mathrm{C}$ (heating rate $50{ }^{\circ} \mathrm{C} / \mathrm{min}$ ) for $4 \mathrm{~min}$ and pressure $50 \mathrm{MPa}$ by SPS technique. For these parameters of sintering a high value of the Vickers hardness equal to $21.0 \mathrm{GPa}$ and low fracture toughness of $3.87 \mathrm{MPa} \mathrm{m}{ }^{1 / 2}$ were obtained. $\mathrm{Al}_{2} \mathrm{O}_{3}-\mathrm{TiC}$ composite powders synthesized by high-energy ball milling were consolidated near to theoretical density $(99.6 \%)$ in SPS at a sintering temperature of $1450{ }^{\circ} \mathrm{C}$ for 4 min at $50 \mathrm{MPa}$ [30]. Grain sizes of both $\mathrm{Al}_{2} \mathrm{O}_{3}$ and TiC were less than $1 \mathrm{~mm}$. The Vickers hardness of $19.1 \mathrm{GPa}$ and fracture toughness of $4.5 \mathrm{MPa} \mathrm{m}{ }^{1 / 2}$ were obtained. $\mathrm{Al}_{2} \mathrm{O}_{3} / \mathrm{TiN}$ nanocomposites with cubic $\mathrm{TiN}$ ( $46 \mathrm{vol} \%$ ) and $\alpha-\mathrm{Al}_{2} \mathrm{O}_{3}(54 \mathrm{vol} \%)$ were synthesized by in situ reactive synthesis (RS) (SPSRS-spark plasma sintering reactive synthesis) at a temperature of $1400{ }^{\circ} \mathrm{C}$, under a pressure of $60 \mathrm{MPa}$, at different dwelling times (0-6 min) starting from a mixture of $\mathrm{TiO}_{2}, \mathrm{AlN}$ and Ti powders [31]. Fine microstructure with TiN particles homogeneously distributed in the $\mathrm{Al}_{2} \mathrm{O}_{3}$ matrix were observed. The Vickers hardness and fracture toughness of samples from an SPSRS were 17.8 GPa, 4.22 $\mathrm{MPa} \mathrm{m}^{1 / 2}$ respectively. For comparison, $\mathrm{Al}_{2} \mathrm{O}_{3} / \mathrm{TiN}$ composites were also prepared at a temperature of $1420{ }^{\circ} \mathrm{C}$ under $60 \mathrm{MPa}$, using mechanically mixed TiN and $\mathrm{Al}_{2} \mathrm{O}_{3}$. These composites revealed slightly higher hardness and fracture toughness.

\section{Conclusions}

In this work, effort has been made to produce alumina-zirconia matrix composites reinforced with TiC and TiN phases as a tool material with improved mechanical properties. This was achieved by using SPS to consolidate the alumina-zirconia powder with the addition of TiC and TiN.

A high-density alumina-zirconia matrix composites with over $98 \%$ density in the temperature range of $1575-1675^{\circ} \mathrm{C}$, Vickers hardness of about $19.0 \mathrm{GPa}$, fracture toughness of over $5.0 \mathrm{MPa} \mathrm{m} \mathrm{m}^{1 / 2}$ were manufactured. These properties were significantly better than those obtained by pressureless sintering at the highest temperature of $1750{ }^{\circ} \mathrm{C}$.

The mechanical properties of the samples sintered at the temperature of $1750^{\circ} \mathrm{C}$ by PS exhibited $5-10 \%$ lower values when compared to those sintered at the lowest temperature $\left(1575^{\circ} \mathrm{C}\right)$ by the SPS method. A lower relative density of $97 \%$ was achieved for the pressureless sintering at a temperature of $17500^{\circ} \mathrm{C}$.

No influence of the sintering temperature on the Vickers hardness of these composites was observed. SPS samples achieved comparable Vickers hardness and Young modulus in the range of the tested temperatures. However, slightly increase of the fracture toughness at the highest temperature was attained. An increase in the wear rate of both the disk and the ball of the tested composites at the higher sintering temperature was observed.

There are differences in mechanical properties of samples with various compositions of zirconia. Samples with tetragonal, yttria-stabilised zirconia (YSZ) phase sintered by SPS, marked as TCN3, had the highest Vickers hardness value of over 19.0 GPa. Samples with monoclinic zirconia phase of $2 \mathrm{wt} \%$ and $5 \mathrm{wt} \%$ sintered by SPS, marked as TCN1 and TCN2 respectively, had the Vickers hardness value less than $5 \%$ lower than that of TCN3 samples. This was related to the highest amount of $\operatorname{Ti}(\mathrm{C}, \mathrm{N})$ as a 
continuous solution of TiN and $\mathrm{TiC}$ for the samples with tetragonal zirconia specimen shown in X-ray diffraction and microstructural observation.

A $10-30 \%$ increase of the fracture toughness was observed for samples with monoclinic zirconia phase when compared to samples with tetragonal zirconia phase.

Author Contributions: Conceptualization, M.S.; methodology, M.S.; validation, M.S.; formal analysis, M.S.; investigation, M.S., S.C., M.P., J.L.-Ł., J.C. and A.K.; resources, M.S.; data curation, M.S.; writing—original draft preparation, M.S.; writing - review and editing, M.S.; visualization, S.C.; supervision, M.S.; project administration, M.S.; funding acquisition, M.S.

Funding: This research and APC was funded by the National Science Centre Poland, grant number UMO-2016/21/B/ST8/01027.

Acknowledgments: This work was supported by the National Science Centre, Poland (project UMO-2016/21/B/ST8/01027) 2017-2020.

Conflicts of Interest: The authors declare no conflict of interest.

\section{References}

1. Bobzin, K. High-performance coatings for cutting tools. CIRP J. Manuf. Sci. Technol. 2017, 18, 1-9. [CrossRef]

2. Pampuch, R. Kompozyty ceramiczne. Kompozyty 2002, 2, 10-14.

3. Tiwari, A.; Gerhardt, R.A.; Szutkowska, M. Advanced Ceramic Materials; John Wiley \& Sons: Hoboken, NJ, USA, 2016; ISBN 1119242738.

4. Szutkowska, M.; Boniecki, M. Fracture toughness of alumina matrix composites (AMC). J. Optoelectron. Adv. Mater. 2010, 12, 301-308.

5. $\mathrm{Ni}$, X.; Zhao, J.; Sun, J.; Gong, F.; Li, Z. Effects of metal binder on the microstructure and mechanical properties of $\mathrm{Al}_{2} \mathrm{O}_{3}$-based micro-nanocomposite ceramic tool material. Int. J. Miner. Metall. Mater. 2017, 24, 826-832. [CrossRef]

6. Yin, Z.; Huang, C.; Zou, B.; Liu, H.; Zhu, H.; Wang, J. Preparation and characterization of $\mathrm{Al}_{2} \mathrm{O}_{3} / \mathrm{TiC}$ micro-nano-composite ceramic tool materials. Ceram. Int. 2013, 39, 4253-4262. [CrossRef]

7. Acchar, W.; Cairo, C.A. The influence of $(\mathrm{Ti}, \mathrm{W}) \mathrm{C}$ and $\mathrm{NbC}$ on the mechanical behavior of alumina. Mater. Res. 2006, 9, 171-174. [CrossRef]

8. Song, S.-X.; Ai, X.; Zhao, J.; Huang, C.-Z. $\mathrm{Al}_{2} \mathrm{O}_{3} / \mathrm{Ti}\left(\mathrm{C}_{0.3} \mathrm{~N}_{0.7}\right)$ cutting tool material. Mater. Sci. Eng. A 2003, 356, 43-47. [CrossRef]

9. Rempel, A.A. Nonstoichiometric transition metal compounds. A review. In Proceedings of the 17th Israeli-Russian Bi-National Workshop 2018, the Optimization of the Composition, Structure and Properties of Metals, Oxides, Composites, Nano and Amorphous Materials, Moscow, Russia, 13-17 August 2018; pp. 167-189.

10. Gusev, A.I.; Rempel, A.A.; Magerl, A.J. Disorder and Order in Strongly Nonstoichiometric Compounds: Transition Metal Carbides, Nitrides and Oxides; Springer Science \& Business Media: Berlin/Heidelberg, Germany, 2013; Volume 47, ISBN 3662045826.

11. Lengauer, W. Transition metal carbides, nitrides, and carbonitrides. Handb. Ceram. Hard Mater. 2000, 202-252. [CrossRef]

12. Rajabi, A.; Ghazali, M.J.; Daud, A.R. Chemical composition, microstructure and sintering temperature modifications on mechanical properties of TiC-based cermet-A review. Mater. Des. 2015, 67, 95-106. [CrossRef]

13. Yu, S.; Zeng, Q.; Oganov, A.R.; Frapper, G.; Zhang, L. Phase stability, chemical bonding and mechanical properties of titanium nitrides: A first-principles study. Phys. Chem. Chem. Phys. 2015, 17, 11763-11769. [CrossRef]

14. Yin, Z.; Yuan, J.; Wang, Z.; Hu, H.; Cheng, Y.; Hu, X. Preparation and properties of an $\mathrm{Al}_{2} \mathrm{O}_{3} / \mathrm{Ti}(\mathrm{C}, \mathrm{N})$ micro-nano-composite ceramic tool material by microwave sintering. Ceram. Int. 2016, 42, 4099-4106. [CrossRef]

15. Rozmus, M.; Putyra, P.; Figiel, P. The influence of non-conventional sintering methods on grain growth and properties of alumina sinters. Mechanik 2015, 88, 249-258. [CrossRef] 
16. Tokita, M. Trends in Advanced SPS Spark Plasma Sintering Systems and Technology. Functionally Gradient Materials and Unique Synthetic Processing Methods from Next Generation of Powder Technology. J. Soc. Powder Technol. Japan 1993, 30, 790-804. [CrossRef]

17. Fang, Y.; Zhao, X.; Zhang, M.; Zhang, P.; Cheng, H.; Xue, S.; Zhang, L.; Wu, J.; Feng, S. Effect of ZrO $Z_{2}$ whiskers on the microstructure and mechanical properties of a $\mathrm{Ti}(\mathrm{C}, \mathrm{N})$-based cermet cutting tool material. Int. J. Appl. Ceram. Technol. 2019. [CrossRef]

18. Li, Q.; Sun, X.D.; Xiu, Z.M. Microstructure and properties of $\mathrm{Al}_{2} \mathrm{O}_{3} / \mathrm{TiCN}-\mathrm{Ni}-\mathrm{Ti}$ composite fabricated by hot pressing. Chin. J. Nonferrous Met. 2012, 22, 2311-2316.

19. Xikun, L.; Guanming, Q.; Tai, Q.; Haitao, Z.; Hua, B.; Xudong, $\mathrm{S}$. $\mathrm{Al}_{2} \mathrm{O}_{3} / \mathrm{TiCN}-0.2 \% \mathrm{Y}_{2} \mathrm{O}_{3}$ composite prepared by HP and its cutting performance. J. Rare Earths 2007, 25, 37-41. [CrossRef]

20. Dyatlova, Y.G.; Agafonov, S.V.; Boikov, S.Y.; Ordanyan, S.S.; Rumyantsev, V.I. Tool ceramics based on $\mathrm{Al}_{2} \mathrm{O}_{3}-\mathrm{ZrO}_{2}-\mathrm{TiCN}$ composite. Powder Metall. Met. Ceram. 2011, 49, 675-681. [CrossRef]

21. Shen, Z.; Johnsson, M.; Zhao, Z.; Nygren, M. Spark plasma sintering of alumina. J. Am. Ceram. Soc. 2002, 85, 1921-1927. [CrossRef]

22. Zheng, Y.; Wang, S.; You, M.; Tan, H.; Xiong, W. Fabrication of nanocomposite Ti (C, N)-based cermet by spark plasma sintering. Mater. Chem. Phys. 2005, 92, 64-70. [CrossRef]

23. British Standards Institution. European Standard EN 623-2:1993 Advaced Technical Ceramics-Monolithic Ceramics - General and Textural Properties-Part 2-Determination of Density and Porosity; British Standards Institution: London, UK, 1993.

24. Klimczyk, P. SiC-Based Composites Sintered with High Pressure Method. Silicon Carbide Mater. Process. Appl. Electron. Devices 2011, 309-334. [CrossRef]

25. Niihara, K.; Morena, R.; Hasselman, D.P. Evaluation of Klc of Brittle Solids By the Indentation Method With Low Crack To Indent Ratios. J. Mater. Sci. Lett. 1982, 1, 13-16. [CrossRef]

26. ISO INTERNATIONAL STANDARD. Fine Ceramics (Advanced Ceramics, Advanced Technical Ceramics)—Determination of Friction and Wear Characteristics of Monolithic Ceramics by Ball-on-Disc Method; ISO: Geneva, Switzerland, 2016.

27. Liu, J.; Li, Z.; Yan, H.; Jiang, K. Spark plasma sintering of alumina composites with graphene platelets and silicon carbide nanoparticles. Adv. Eng. Mater. 2014, 16, 1111-1118. [CrossRef]

28. Tokita, M.; Tamari, N.; Takeuchi, T.; Makino, Y. Consolidation behavior and mechanical properties of SiC with $\mathrm{Al}_{2} \mathrm{O}_{3}$ and $\mathrm{Yb}_{2} \mathrm{O}_{3}$ consolidated by SPS. J. Jpn. Soc. Powder Powder Metall. 2009, 56, 788-795. [CrossRef]

29. Orru, R.; Licheri, R.; Locci, A.M.; Cincotti, A.; Cao, G. Consolidation/synthesis of materials by electric current activated/assisted sintering. Mater. Sci. Eng. R Rep. 2009, 63, 127-287. [CrossRef]

30. Zhang, Y.F.; Wang, L.J.; Jiang, W.; Chen, L.D. Preparation of $\mathrm{Al}_{2} \mathrm{O}_{3}-\mathrm{TiC}$ Composites by High Energy Ball Milling Combined with SPS Technology and Its Properties. J. Inorg. Mater. 2005, 20, 1445-1449.

31. Wang, L.; Wu, T.; Jiang, W.; Li, J.; Chen, L. Novel fabrication route to $\mathrm{Al}_{2} \mathrm{O}_{3}-\mathrm{TiN}$ nanocomposites via spark plasma sintering. J. Am. Ceram. Soc. 2006, 89, 1540-1543. [CrossRef]

(C) 2019 by the authors. Licensee MDPI, Basel, Switzerland. This article is an open access article distributed under the terms and conditions of the Creative Commons Attribution (CC BY) license (http://creativecommons.org/licenses/by/4.0/). 